\title{
Flow. An exploration of the mindsets and behaviours of designers in their creative ecosystem
}

Raul Sarrot is a multidisciplinary designer, strategist, researcher, design thinking coach and senior lecturer that specialises in delivering game-changing design programmes in all areas, from high-level strategies to brand creation and storytelling. Raul's international trajectory has been forged over 27 years working alongside a wide range of individuals and enterprises in Asia Pacific, the Americas and Europe. Raul is the founder and director of Freshfish, a boutique design innovation studio specialised in strategy, branding and communications and also is a Senior Lecturer at AUT (Auckland University of Technology, Aotearoa New Zealand) and a guest lecturer at other universities around the world. $<$ raul@freshfish.co.nz > ORCID: 0000-0003-1819-626X
Abstract How Designers transcend the barriers to creativity to achieve an ideal state of flow during their creative process? Tracing parallels between Design education and industry-based practice, Flow is an article that explores the mindsets and behaviours of Designers in their ecosystems and the challenges surrounding them. The exploratory journey advanced in the manuscript is based on foundational art essays blended with different points of view from traditional designers and Positive Psychology concepts. Aditionally, it builds on the author's previous research developed on Flow and aimed to challenge paradigms and contrast core design principles and philosophies. Its purpose is to better understand what are the tensions between the different creative processes like the individual spark of creativity, the playful serendipity, the inventor's light bulb, the apprentice-master craftsmanship model and other contemporary methodologies such as Design Thinking and Agile. Nevertheless, it inspect how all of these approaches relates to the context of the designers' ecosystem and the challenges they face when designing. As a piece of research, Flow does not offer final crystalised answers or solutions yet instead poses critical questions and offers an open dialogue with diverse points of view.

Keywords Flow, Creative Process, Mindsets, Behaviours, Design 


\section{Fluxo. Uma exploração das mentalidades e comportamentos dos designers em seu ecossistema criativo}

Resumo Como os designers transcendem as barreiras da criatividade para alcançar um estado de fluxo ideal durante seu processo criativo? Traçando paralelos entre a educação em design e a prática baseada na indústria, Flow é um artigo que explora as mentalidades e comportamentos dos designers em seus ecossistemas e os desafios que os cercam. Com base em ensaios de arte fundamentais e combinando diferentes pontos de vista de designers tradicionais, juntamente com conceitos de psicologia positiva e pesquisa previa produzida pelo autor, Flow desafia paradigmas e contrasta princípios e filosofias de design. $O$ objetivo é entender melhor as tensões entre os diferentes processos criativos, como a centelha individual de criatividade, a serendipidade lúdica, a lâmpada do inventor, o modelo mestre aprendiz e outras metodologias contemporâneas, como Design Thinking e Agile, se relacionam com os ecossistema criativos dos designers e os desafios que eles enfrentam ao criar. Flow não oferece respostas ou soluções cristalizadas finais, mas, em vez disso, coloca questões críticas e oferece um diálogo aberto com diversos pontos de vista.

Palavras chave Flow, Processo criativo, Modos mentais, Comportamento, Design.

Flujo. Una exploración de la mentalidad y el comportamiento de los diseñadores en su ecosistema creativo

Resumen ¿Cómo traspasan los diseñadores las barreras de la creatividad para lograr un estado de flujo óptimo durante su proceso creativo? Trazando paralelismos entre la educación en diseño y la práctica basada en la industria, Flow es un artículo que explora las mentes y los comportamientos de los diseñadores en sus ecosistemas y los desafíos que los rodean. Basado en ensayos de arte fundamental y combinando diferentes puntos de vista de diseñadores tradicionales, junto con conceptos de psicología positiva e investigaciones previas producidas por el autor, Flow desafía paradigmas y contrasta principios y filosofías de diseño. El objetivo es comprender mejor las tensiones entre los diferentes procesos creativos, como la chispa individual de la creatividad, la serendipia lúdica, la lámpara del inventor, el modelo maestro aprendiz y otras metodologías contemporáneas, como Design Thinking y Agile, relacionadas con lo creativo ecosistemas de los diseñadores y los desafíos que enfrentan al crear. Flow no ofrece respuestas ni soluciones finales cristalizadas, sino que plantea preguntas críticas y ofrece un diálogo abierto con diferentes puntos de vista.

Palabras clave Flujo, proceso creativo, modos mentales, comportamiento, diseño. 


\section{Introduction}

How designers work and their creative processes is a question and field of study that continues to spark many pages of research theory. So are the conversations and debates around the role and purpose of design, that vary through time and fuel passions and ignite debate. Similarly, the designers' work itself -the outputs of their work- is often evaluated, judged and eventually acknowledged in many different Design events, awards and publications. Although all of this forms part of a Designer's ecosystem and is related to this study, it is not the fundamental aspect explored in this paper. Flow focuses specifically in exploring the mindsets and behaviours of Designers in their ecosystems and in understanding what are the barriers -and the context- when facing creative challenges.

\section{Framing the understanding of a creative ecosystem ${ }^{1}$}

We can analyse the designers' creative ecosystems in many different ways. Even today, when we live -and work- in an interconnected global economy there are specific societal and cultural aspects that influence the mindsets and behaviours of designers and therefore they also influence their work.

As one research lens for this study we approach the analysis through Hundertwasser ${ }^{2}$ 's Man's Five Skins theory. His quote and drawing below represents the five skins that informs his philosophy:

For Hundertwasser, man has three skins: his natural epidermis, his clothes, his house. When in 1967 and 1968 the artist delivered his "Naked" address to proclaim man's right to his third skin (the free alteration of his house), he accomplished the ritual full cycle of his spiral. He re-found his first skin, that of his original truth, his nakedness as a man and painter, by stripping off his second skin (his clothes) to proclaim the right to his third skin (his home). Later, after 1972, when the major ideological turning-point had been passed, the spiral of Hundertwasser's chief concerns began to unfold. His consciousness of being was enriched by new questions, which called fresh responses and elicited new commitments. So appeared the new skins that were to be added to the concentric envelopment of the three previous ones. Man's fourth skin is the social environment (of family and nation, via the elective affinities of friendship). The fifth skin is the planetary skin, directly concerned with the fate of the biosphere, the quality of the air we breathe, and the state of the earth's crust that shelters and feeds us. ${ }^{3}$ 


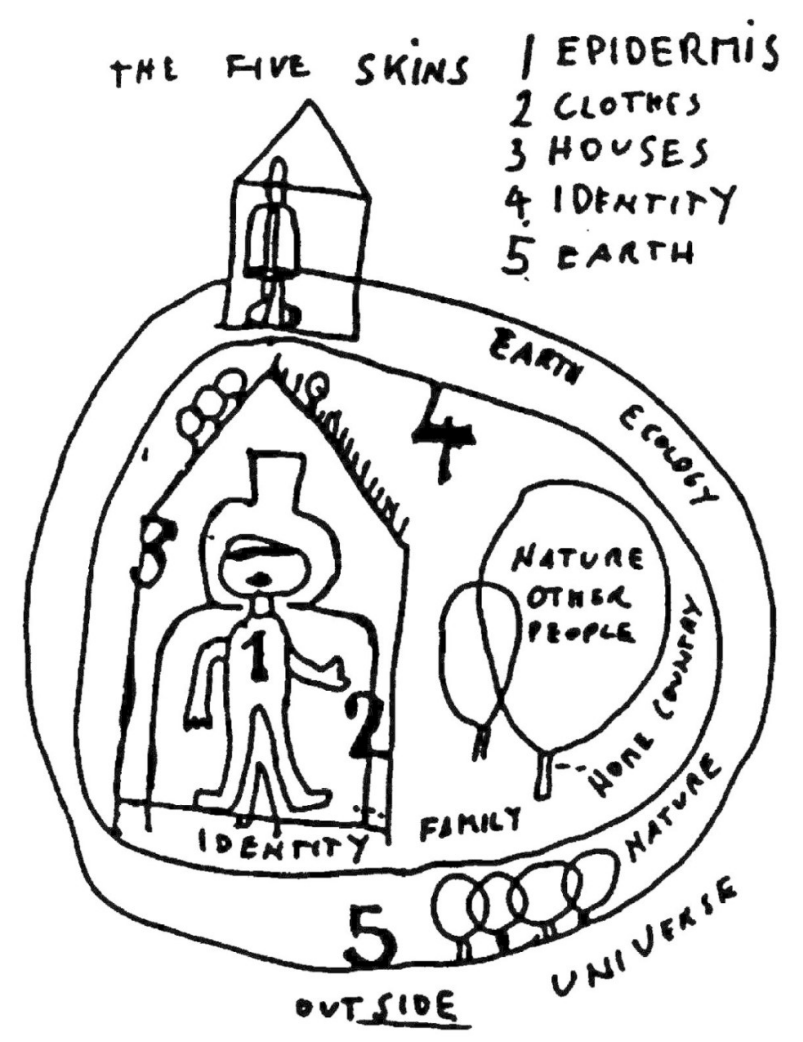

Fig 1. Hundertwasser's Men's Five Skins theory. For Hundertwasser, man has three skins: his natural epidermis, his clothes, his house. When in 1967 and 1968 the artist delivered his "Naked" address to proclaim man's right to his third skin (the free alteration of his house), he accomplished the ritual full cycle of his spiral. He re-found his first skin, that of his original truth, his nakedness as a man and painter, by stripping off his second skin (his clothes) to proclaim the right to his third skin (his home). Later, after 1972, when the major ideological turning-point had been passed, the spiral of Hundertwasser's chief concerns began to unfold. His consciousness of being was enriched by new questions, which called for fresh responses and elicited new commitments. So appeared the new skins that were to be added to the concentric envelopment of the three previous ones. Man's fourth skin is the social environment (of family and nation, via the elective affinities of friendship). The fifth skin is the planetary skin, directly concerned with the fate of the biosphere, the quality of the air we breathe, and the state of the earth's crust that shelters and feeds us.

Although Hundertwasser's 5 skins philosophy was originally conceived in the " 60 s and further developed in the following decades, we can clearly see how today -with all the environmental and pandemic challenges that our world is facing-could transcend time and recover renewed meaning. Particularly Hundertwasser's fourth and fifth skins -the ecology and the wellbeing of mankind- offer a meaningful lens that we could further utilise when analysing the mindsets and behaviours of designers in their ecosystem. In other words, our context and our role, where we are designing from, who for/with and where are our audiences, and how each component of the ecosystem relates to each other. 


\section{Us, them and the world: designers, clients, audiences and the world we live in}

To understand the designers' ecosystem, we propose a micro/macro approach. A zoom in into our realities to then 'zoom out' to our world. We -as designers- are people offering design services to other people (the client or commissioner of our work) and design for yet other people (the desired target audience identified or defined by the brief). Sometimes we are the creators, others the translators or the 'medium' of diverse visual outputs and/or physical solutions aiming at creating a better world. That is or should our task: create a better world. This world could be quite literal or metaphoric, as wide or as narrow as required, depending on what the brief is and the defined target audience wants and/or needs are).

Whichever the case, there seems to be an omnipresent challenge. A meta challenge that sits behind every project and goes beyond any specific brief, budget allocation, country we operate in or design for or even the medium selected to portray our work: people. It is precisely the understanding of people and their mindsets and behaviours in their ecosystems that becomes one of the key challenges of our discipline and therefore a very important part of our own ecosystem.

\section{The art of being present in a future-focussed world Deep practice and meaningful outcomes}

\footnotetext{
Lots of people are talking about the future, but there's a lot to be learnt about the present. We need to design for the future but we also need to be fully present in the world and the context we live in. A, Creative Director. (Sarrot, R. Flow, 2020)
}

As designers, we are familiar with the concept of the future. When we design for a new product or service; a new market, a new audience or a new media or platform, being familiar with the concept of the Future becomes part of our job and -as such-becomes part of our design mindset and plays a role in our behaviours. We are creatives and visionaries therefore standing in the present and designing for the future seems to resonate with our ethos as designers.

What is interesting to observe is how the future -as a concept- has rapidly and radically been permeating through most of the design discourse to a point that at times has become the trending topic -if not the only topic. Regardless if it is on informal conversations or on specialised LinkedIn Design groups or forums; in well-known Design websites, publications or in 
well-respected conferences (either physical or digital) designers are bombarded with articles, courses and conferences about the Future. One can attend to Designing for the future, The future of Design, The future of Business and even The future of the future just to mention a few.

Applying a Design Thinking lens asking 'I wonder if', we are left to wonder how being so exposed to a future-focussed world, affect our mindsets as designers when paradoxically we live in Covid-ridden world that seems to be claiming for urgent human-centred and environmentally-focused actions to address some burning issues. Is the 'gap' between the conversations we are having and the actions we are taking (or should be taken) widening creating a dystopian reality?

\footnotetext{
Instead of empathy as the result of long-term immersion in a culture, we have 2-hour sessions where we gain a scratch-the-surface understanding of the business needs. Instead of Osborn's view of structured brainstorming, we have chaotic 'working sessions'. Instead of a view of design as a way of understanding culture and carefully shaping it through craft and care, we appropriate it as a way of driving innovation through a relentless pursuit of newness. And instead of beautiful, usable, significant and relevant designed things, we have "canvases" and "playbacks" and "design sprints"-and lots and lots of post-it notes. (Kolko, 2018)
}

When Sarrot (2020) as part of his research enquires interviewees about how aware designers were of the need of being present during the process of creativity, he highlights the thinking from a Futurist:

My short answer is people - including myself - think they're being creative when we're not. The world is filled with smart creative people all looking at similar things. So to go beyond, first we need to spend more time looking at what's all around us that we haven't noticed, only then can we truly go beyond!. D, futurist

\section{Design in the times of Pandemic. Zoom meets slow culture}

As part of being present and connected with the world we live in and design for- we should acknowledge and reflect on the impact Covid 19 has had and the crude new realities and paradigms it unveils. The impact and consequences of the pandemic are still being measured and estimated. News about ongoing lockdowns and vaccine programmes are constant news that affect our lives, from health and wellbeing to business and travel. 
So why this 'new normal' has to do with Design, designers and their ecosystems? As society and the wellbeing of people in particular are a key focus of our work, they are also a fundamental part of our ecosystems. In other words, if the world has changed, our ecosystems have dramatically changed too.

The way we did business and connected with people pre Covid 19 times has changed dramatically and there's no indication of when (or if) things will go back to what we once knew as 'normality'.

What before was a face to face meeting with a customer or a Design class in an open studio, now is likely a call on some digital platform. What used to be on the ground primary research in foreign markets now has been postponed or deferred to local researchers or designers working on that specific field. Travelling, for business meetings, conferences or research missions- has diminished significantly if not halted completely. Now, instead, we 'zoom' into people's lives as a normality. Seeing people in their living rooms, kitchens or spare rooms improvised as a home office is almost normal. The other option is to observe people badly 'clear cut' into fake generic backgrounds. Someone in at their home office in Chile like floating behind the Niagara Falls or the Big Ben. Kids running behind scenes or dogs barking interrupting a meeting or a briefing session is now as much of a common occurrence as in the past a secretary would knock at the boardroom door to offer coffee. Furthermore, people's 'body language' during these digital meetings, creative presentations or an online class is now circumscribed to, in the best of the scenarios, a 4:3 thumbnail view of head and shoulders. This is if we are lucky enough to have a good stable internet connection, if someone has not forgotten (or decided not to) turn on their video cameras or if there are not that many people on the call that we can hardly recognise or even see their faces. These situations produce an interesting clash, a strange collision between the agility of digital technologies and the slow culture of the home environment.

To counterbalance this very challenging world scenario we can also observe and appreciate some very interesting and hopefully positive arising insights. Businesses, clients and institutions, by will or by force, are becoming more open and accepting of people's realities and also are more open to their needs and wants.

During Zoom calls, sometimes you have the possibility to see -and get closer- to people's realities by literally having a window to the heart of their homes, their natural habitat (what Hundertwasser called the Third Skin). Observing that environment could offer a more human (or real) perspective and adds a new lens to the relationship we might have had with each other. Starting an online meeting with a check in to see how people are in is becoming common practice. Empathy is becoming common practice and we all are becoming more aware of the importance of wellbeing. It could be observed that even what previously could have been cold business conversations are now sometimes becoming more relaxed -or more human- perhaps to counteract the lack of humanity that screen interfaces offer. 


\section{Moving from challenges to opportunities. Understanding Flow}

On the previous sections of this paper we partially explored the context of the world we live in, the impact of the Pandemic and how this affects lives and particularly the ecosystem of designers. We offered Hundertwasser's 'Five Skins' as a research lens and consider the need of being present and also explored the new dynamics and meaning of remote meetings and zooming into people's lives.

In this section, we explore further what are the ideal contexts and environments in which we-designers- thrive. What are those optimal conditions that allow the designers' mindsets and behaviours to focus into the work and perform at the best of our capacities to deliver the ideal results (from an experiential point view in the creative process and from an output and outcome point of view).

Often companies ask employees to do deeper creative work on top of their existing workload and make no allowances for that to happen. The existing organisational culture, structures and hierarchies prevent designers from thinking differently and act on innovation. $\mathrm{S}, \mathrm{HCD}$ and CX designer

Flow is a theory developed by Mihaly Csíkszentmihályi as part of his work Flow, The Psychology of Optimal Experience. Csíkszentmihályi studied what is the ideal balance between challenges and skills to keep people 'flowing' into their chosen activity. He defined the optimal experience when someone is on the 'Flow Channel', a situation where there's a balance between the challenges presented and the skills developed. He explains how too many challenges and not enough skills lead to anxiety and -on the other hand- and abundance of skills not meeting interesting challenges or not enough of them lead to boredom (see Figure 2).

As exposed before, we live in a complex, challenging world. Some of those macro challenges have been explored earlier on this paper. Some are well known and obvious, some might not be so much. Of course, to that 'big picture' we have to add the micro challenges or specific to the different cultures, regions, countries or -even more granularly- to teams and organisations. Then we also have the personal challenges arising from personal situations. There is no shortage of challenges. Now what are the new set of skills that we-designers- need to develop to face such challenges? Now we enter the territory of not only 'the ideal' flow scenario, but also the fundamental need to take care of our mental health and wellbeing as designers to avoid falling into anxiety or any other undesired state that could affect our mindsets and behaviours. 
Fig 2. Csikszentmihalyi's flow channel shows the relation between challenges and skills in order to create an optimum experience in goal-driven activities. Adapted from Csíkszentmihályi (2008).

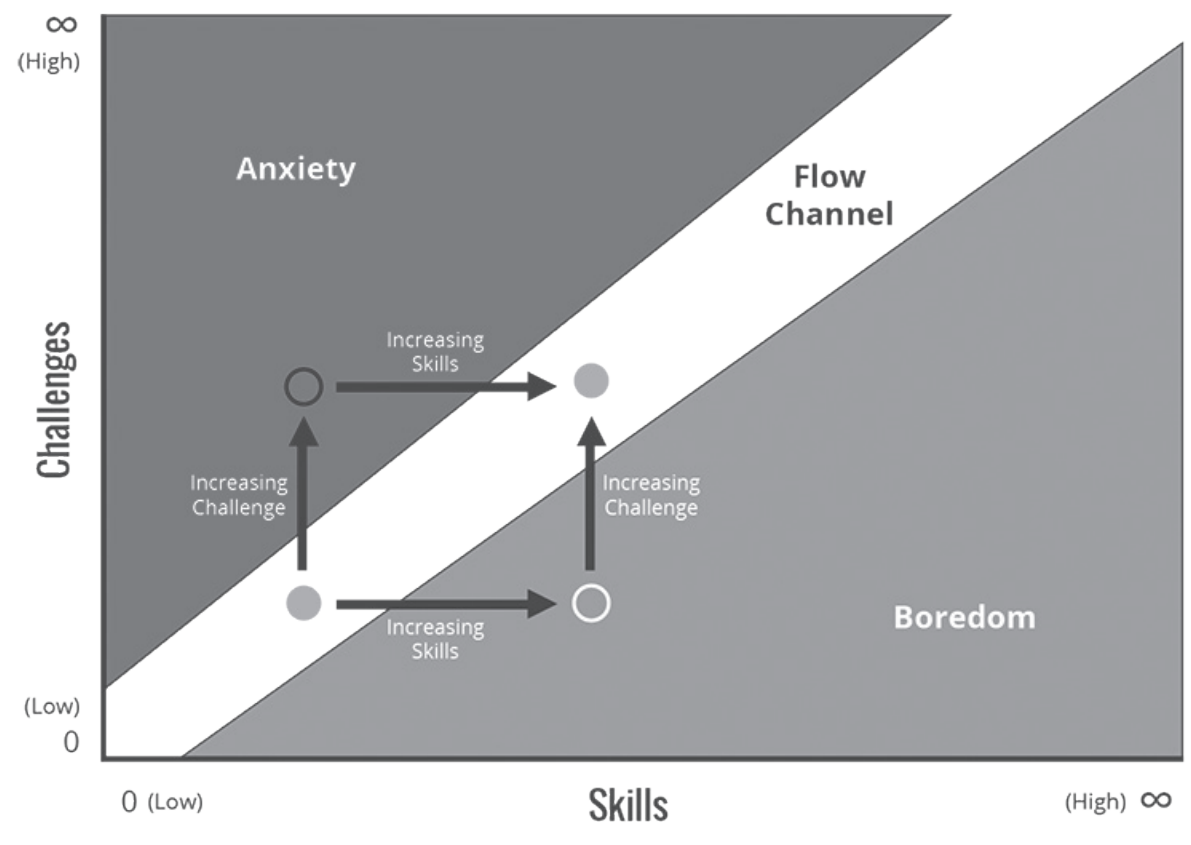

The bigger question here is not only what is required from us -designers- but also what is required from the businesses and/or organisations we work for or with. What will empower us so we can empower them. What would generate a healthy, sustainable and abundant ecosystem that will allow us to thrive?

\section{Karanga. All call to action}

What can we learn from all this? How might we translate the current and arising challenges of the post-pandemic world we live in into game-changing opportunities? How might we adapt our mindsets and behaviours to redesign the way we work and the way we approach Design? How might we develop a new set of skills to find our ideal flow channel?

Need or opportunity, there seems to be a clear call to evolve the traditional views and roles of Design. An opportunity to evolve the role of Design from the foundational Bauhausian principles of form and function that influenced the Design philosophy in the 20th century. A co-created movement from design researchers and practitioners to recover or discover meaning and purpose of Design. A shift from the underlying Freudian will to pleasure (often practiced by designers when embracing the act of creation or designing as self-fulfillment) or from Ardler's will to power (embraced by so many teams, businesses and corporations). Victor Frankl's Logotherapy describes this as will to meaning. 
Our responsibility as designers is to give a new meaning to Design and to its role in society. A role that recognises the world we live in and acknowledges the current and upcoming needs of humanity and the environment. And this is the aim of this paper: to ignite conversations and reflections to enrich the Design discourse and to allow flow. The responsibility and the opportunity of contributing meaningfully to a prosperous society is in our hands.

\begin{abstract}
1 The Environment of Ecosystem
For the now-ubiquitous prefix eco, we can thank the great German zoologist Ernst Haeckel, who in 1866 coined the term oekologie from the Greek oikos, meaning "home, place to live." Haeckel was thinking primarily of the "homes" of animals, but by the time the word translated into English in 1875 (initially spelled "oecology"), its meaning had broadened to embrace plant habitats as well. The related term ecosystem was proposed by the British botanist Arthur Tansley, 60 years after one of his own professors first translated Haeckel's oekologie. It may have been ecosystem, which treats eco- as a prefix to a standard English word, that gave English speakers permission to do the same in coining a host of other terms: ecosphere, ecotour, eco-friendly, and all the rest. Meanwhile, ecosystem itself has been appropriated freely in all kinds of contexts well removed from the natural environment: the "app ecosystem," the "education ecosystem," the "startup ecosystem," the "pop-culture ecosystem," the "mobile ecosystem," the "biking ecosystem," and so forth. https://www.merriam-webster.com/dictionary/ecosystem?src=search-dict-box\#note-1

2 Friedensreich Hundertwasser (1928-2000) was a prominent Jewish-Austrian artist and environmental activist.

3 (Pierre Restany, in: The Power of Art, Hundertwasser - The Painter-King with the five skins, Cologne, 1998, pp. 10-11)

4 In positive psychology, flow is the state in which a person is fully focussed and effortlessly enjoying an activity. In essence, flow is characterized by the complete absorption in what one does, a state of happiness resulting in a temporary loss of the sense of time. Concept named by Mihály Csíkszentmihályi in 1975 the concept has existed for years under different names.
\end{abstract}

\title{
References
}

Csíkszentmihályi, M. (2008). Flow. The Psychology of Optimal Experience. Harper Perennial Modern Classics.

Frankl, V.E. (1971). The Will To Meaning: Foundations And Applications Of Logotherapy. Souvenir Press.

Kolko, J. (2018). The Divisiveness of Design Thinking. Interactions Magazine, XXV.3, May-June.

Restany, P., (1998). Hundertwasser: The Painter-king with the 5 Skins: the Power of Art. Taschen.

Sarrot, R. (2020). Flow. What are the barriers creatives find during the design process? Interviews with Designers. Unpublished manuscript.

Recebido: 03 de março de 2021. Thomson, R. (1959). The Psychology of Thinking. Pelican A453. 